\title{
Air / Sea Rescue Launches
}

\section{Cdr W. H. Rice*}

The Motor Boat Wing of the South African Air Force was inaugurated some thirty eight years ago.

With its main base at Gordon's Bay, the wing was formed to operate the various marine craft used to provide a service to the flying component of the South African Air Force. Its main function was to be air/sea rescue, but it also had to man and maintain armoured target boats, seaplane tenders, marine tenders and the 'bomb scows', used for recovering practise bombs and missiles and for laying and lifting moorings.

The first batch of boats was ordered in the late 1930's from the British Power Boat Co of Hythe, Southern England. This company, which for years had been building fast launches for work and pleasure, was owned by Hurbert Scott-Paine, designer of some of the first British seaplanes, including Schneider Trophy contenders.
During the early 1930's, Scott-Paine was locked in a fierce struggle with his main rival, John I. Thorneycroft, for the contract to re-equip the Royal Navy's Coastal Forces Section which had been moribund since 1918. This struggle led to rapid advances being made in hull, propeller and engine technology of fast boats during the period.

Although Thorneycroft gained the contract with a 44 knot design, six of Scott-Paine's $60 \mathrm{ft} 33$ knot boats were accepted by the Royal Navy in 1936, and formed the first Motor Torpedo Boat Squadron. During this period the firm also produced a $64 \mathrm{ft}$ twin screw boat capable of 40 knots. In place of the three 500 horsepower Napier Lion engines of the Motor Torpedo Boat, this craft had two Rolls Royce Merlin engines, giving it an additional 700 or so horsepower.

\footnotetext{
* Cdt Rice is at present manager of Naval Dockyard at Simonstown
}

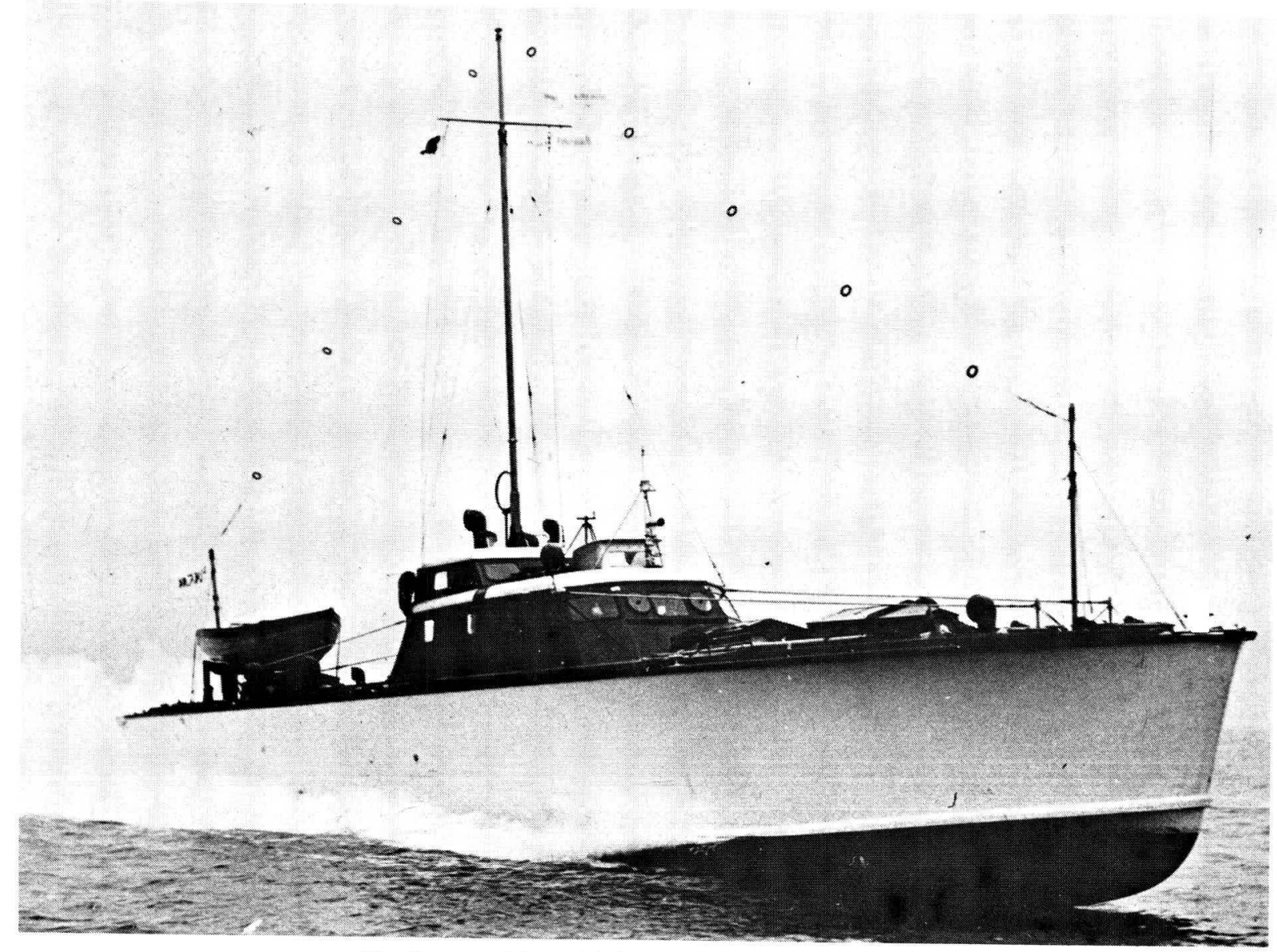

The first crashboat Malmok - later renumbered RO 
It was this boat which the Government of the Union of South Africa selected to equip the air/sea rescue section of the South African Air Force Motor Boat Wing. A number were duly ordered.

The first so-called 'crashboat' was off-loaded at Cape Town in 1940, and motored round to the newly established base at Gordon's Bay. There she was accepted and named Malmok, after the black browed Albatross of the Cape Seas.

Also from the British Power Boat Co came armoured target boats and seaplane tenders, two of which are still in service at Langebaan.

Unfortunately the delivery of Malmok coincided with the end of the so-called 'Phoney War' and the start of the 'Battle of Britain'. The Merlin engines for one air/sea rescue launch could put two Spitfires in the air to fight off the Luftwaffe so the balance of the South African order was cancelled, or at least, suspended.

The South African Air Force was thus left, at a time when the assault on Allied shipping on the South African Coast by surface raiders and submarines was beginning to 'hot up', with only one seagoing rescue launch. Malmok was kept very busy indeed, and the crews of many mined and torpedoed merechant ships owe their lives to her and her crew.

With the British war effort already over-extended in its attempts to stem the German onslaught, South Africa turned to the United States of America as a supplier of military equipment. The purchasing mission to the United States, known as Sapurcom, was directed to acquire a number of fast rescue launches to supplement the overworked Malmok.

No such boat was available 'off the shelf', but a University of Michigan Naval Architect named Dare Long agreed to design one using the performance specification for the 64 British Power Boat Co launch as his guide.

The design was soon completed and an order for eight boats was placed with the Miami Shipbuilding Corporation in Florida.

Because the Americans had no equivalent to the 1100 horsepower Merlin, two horsepower petrol engines were to be mounted in tandem on each of the two shafts. The Kermath Sea Raider was the engine selected for the job. Aircraft construction techniques were employed to keep the weight of the boat to a minimum. It was later found that construction had been too light in some areas, especially the engine bearers which collapsed due to the pounding they received off the Cape Coast.

Within weeks the first boat was ready for trials. A speed of over 40 knots ( 74 kilometres per hour) was achieved in the full power trial off the Florida coast, and the first four boats were sent to Port Everglades where they were loaded aboard an American cargo vessel for shipment to the Union. There was, at that time, no danger of the precious boats being lost in transit due to enemy action.

America was still neutral and her ships, invulnerable to attack,sailed with deck and navigation lights blazing at night and had their national flag painted as large as possible on their sides for daylight identification.

The four so-called Miami boats arrived at the Cape in May 1941, followed two months later by another four. Instead of having names, the boats were numbered R1 to R8. Malmok was also given a number in the series. As she had been the first on station the number had to be RO.

The arrival of the Miami boats made possible the establishment of Flights of Cape Town, Mossel Bay, Port Elizabeth and East London. A double flight was established at Durban, which was an important seaplane base as well as a major commercial port. The main base and maintenance headquarters remained Gordon's Bay.

As was mentioned earlier, engine bearers collapsed due to the pounding the boats suffered, and had to be rebuilt to a more robust design. Radio sets supplied could not survive in the boats and were replaced by aircraft sets mounted down below and as far aft as possible to minimise the bumping.

Magnetic compasses went haywire in their gimbals at 40 knots, in any sort of seaway. The South African Air Force instrument makers devised a custom built model specially for the crashboats which would give an accurate bearing no matter how the boat was performing.

Boats based east of Port Elizabeth experienced problems with the teredo worm which ate its way into the keel and hull planking. Eventually a bitumen/ paraffin solution was found which soaked into the timber and spoiled the taste for the boarers. 
Whatever the problem the maintenance men managed to overcome it somehow. This included the salvage of boats which had gone aground around the coast and had to be patched, refloated and returned to Gordon's Bay for repairs. A lack of equipment and facilities bred tremendous resourcefulness in the men of the Motor Boat Wing.

Maintenance facilities for the flights based at commercial ports were non-existent. However, with aircraft being shipped in from the United States, there was a fairly plentiful supply of large wooden crates. These were soon made weathertight and were modified to serve as quayside workshops and offices.

The hard pressed boats and their crews gained a respite when, in January 1944, the first of eleven new boats arrived. These boats were also Maimi built and incorporated improvements found necessary during operation of the first eight boats.

The main difference externally was that the new boats had 'flying bridges' which gave the coxwain a much better view. With America well and truly in the war and having to economise on strategic materials, the silicon bronze fastenings of the first boats had been replaced by galvanised mild steel which could not be expected to last so long in a marine environment. The boats were given the patent South African Air Force anti-toredo treatment before being put into service. They were numbered R9 to R19 respectively. However R13 was extremely unpopular among the superstitious seafarers and was renumbered R20, leaving the unlucky number vacant.
The arrival of the new boats made it possible to have at least two boats per flight to ensure that one was ready to go at any time.

It is a tribute to the men of the Motor Boat Wing that only one boat, R10, was 'written off' during the war.

R10 was, in fact, salvaged after grounding at Swartklip in the latter days of the war and towed back to Gordon's Bay. With enemy activity around the coast dwindling she was considered to be beyond economical repair and was stripped of her engines and equipment. Shortly after the cessation of hostilities she was broken up.

Two other serious groundings occurred during the war, one on Robbeneiland and the other at Stilbaai. Both boats were salvaged and returned to service with the minimum delay.

During the war the main base for the Wing was moved to Robbeneiland and later Langebaan. When hostilities ceased the Wing was downgraded to a Squadron. Outlying operational bases were closed and the number of personnel employed reduced. If the estimated cost of repairs or overhaul were considered to be uneconomical a boat was stripped of useful equipment and offered for sale. First to go was the damaged R10 which was closely followed by R0, formerly Malmok. Her two Merlin engines were removed and sold separately. By 1948 a further seven boats, R1, 3, 5, 6, 7 and 8 had also been sold. Gordon's Bay was retained as a maintenance base until 1957 when only R2, 9, 11, 18,19 and 20 remained in service.

Many of the boats became fishing boats, pleasure boats or houseboats.

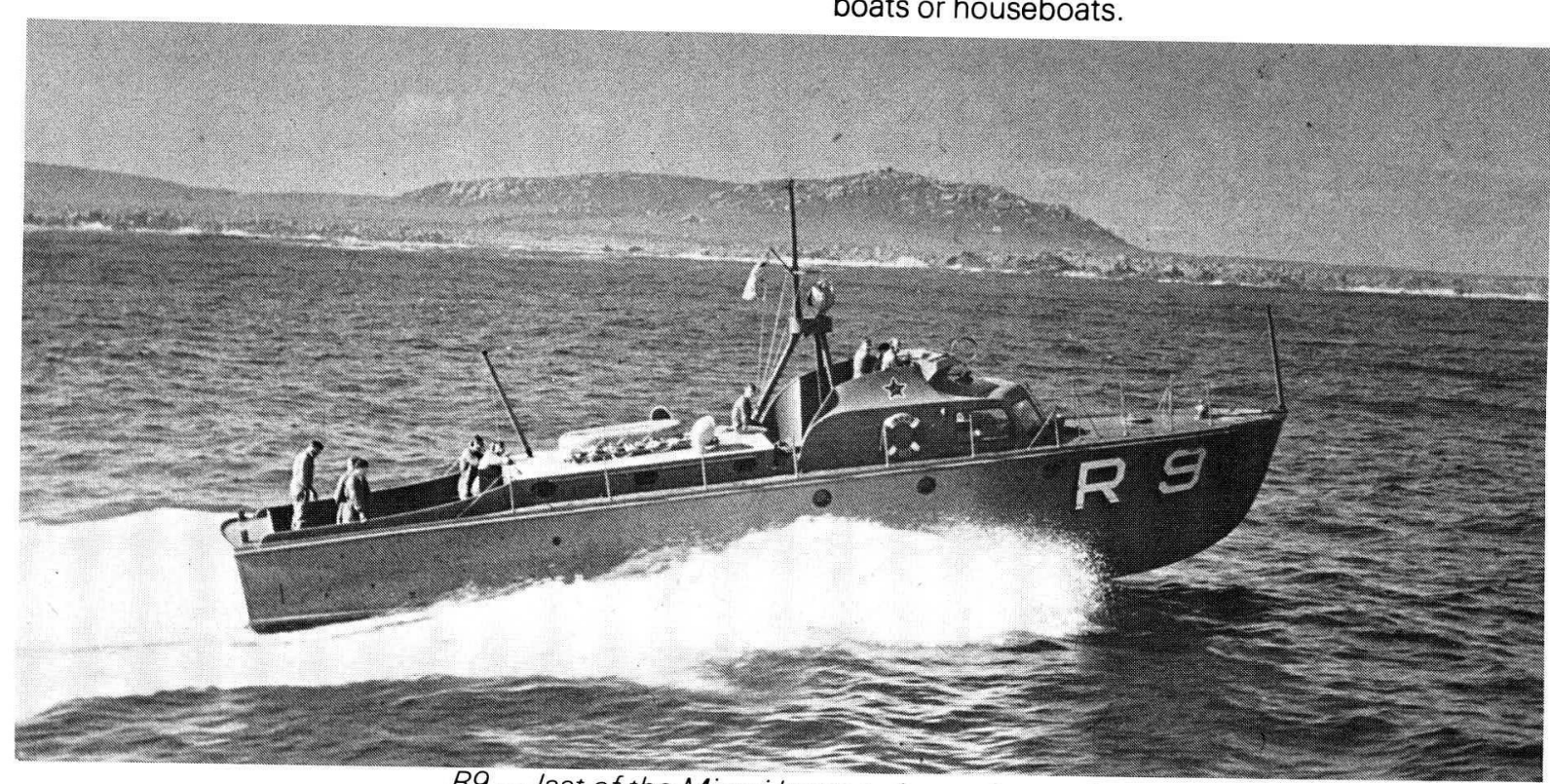

R9 - last of the Miami boats to leave the service. 
Two were purchased in the late 1940's by a Cape Town man who intended to take them to the Mediterranean and use them for smuggling Jews into Palestine. It is believed that one of them, R7, got as far as the Mediterranean. The other one, R3, certainly did not. R6 was bought by the late $\mathrm{Mi}$ nister Dönges and was used as a houseboat at Gordon's Bay. R19 was bought for a European trip which didn't take place.

The South African Air Force proposed to convert one of their last boats, R2, to a VIP ferry for the Robbeneiland service. Plans were drawn up but the conversion never took place.

In 1961 and 1962 the South African Air Force took delivery of two $96 \mathrm{ft}$ German built rescue launches, allowing more Miami boats to be phased out. In 1969, when the South African Navy took over the base at Langebaan, only R9, which had been extensively rebuilt after the war, remained of the original 19. She was renumbered $P 1553$ for the remaining few years of her service life and in 1973, after delivery o two new $64 \mathrm{ft}$ GRP launches, she was boarded and so!d to Mr Ken Evans of Hout Bay.

Several of the old boats can still be seen in Cape
Waters. At Hout Bay R9 is being rebuilt while her sister, Circe (formerly R18), takes passengers for trips around the Bay. The lona which burnt out recently in Kalk Bay, and her successor lona 2 were both crashboats. There is one very sad looking old crashboat at a mooring near the railway station at Simonstown.

Also resident in Simons Bay is Zest, formerly R3, which is used to service tankers visiting False Bay.

While the Suez Canal was closed Zest was kept busy running out to tankers and other ships which preferred to call into False Bay rather than Table Bay during the winter months when the north wester blows. Due to the world-wide shipping slump the bay has had few such visitors in the last year or so.

The story of the Miami boats has a special relevance for us in our present situation. It illustrates that when people have to make do with what they have, resourcefulness and initiative can make what they have effective. It also shows that with good maintenance and a little tender loving care, capital equipment can be made to outlive its intended lifespan by a wide margin. 